\title{
Arsenic, manganese, and dissolved organic matter biogeochemistry in the Bengal Basin (India) and Southern Pampean plain (Argentina)
}

\author{
M. Vega ${ }^{1}$, S. Datta ${ }^{2}$, N.N. Sosa ${ }^{3}$, H. Kulkarni ${ }^{2} \&$ M. Berube ${ }^{2}$ \\ ${ }^{1}$ Hydrologic Science and Engineering Program, Colorado School of Mines, Golden, CO, USA \\ ${ }^{2}$ Department of Geology, Kansas State University, Manhattan, KS, USA \\ ${ }^{3}$ Centro de Investigaciones Geológicas (CONICET-UNLP), Universidad Nacional de La Plata, La Plata, Argentina
}

SUMMARY: Arsenic (As) and manganese (Mn) biogeochemistry is intimately linked with dissolved organic matter (DOM) in subsurface aqueous environments. In this study, we explore the role of contrasting DOM quality on the distributions of $\mathrm{Mn}$ and $\mathrm{As}$ in groundwater. Tubewell and subsurface sediment samples were collected from Murshidabad, West Bengal (WB), India, as well as the Claromecó basin of Argentina. A parallel factor (PARAFAC) model is presented for WB samples that delineate key DOM components in sites characterized by high concentrations of both Mn and As (HMHA), and high Mn concentrations but low As (HMLA). An association between humic-like DOM and elevated As is clear, whereas Mn concentrations are high in the presence of both humic and protein-like DOM. In Claromecó basin groundwaters, an inverse relation between As and $\mathrm{Mn}$ is presented and future efforts are planned to incorporate the role of DOM.

\section{INTRODUCTION}

The arsenic (As) calamity in Southeast Asia has been a significant area of research for decades. More recently, concern over manganese (Mn) in drinking water has inspired work to assess the extent of Mn contamination and associated health impacts. Despite numerous reports of Mn inhibiting the intellectual development of children, increasing infant mortality rates, and causing Parkinson's like neurological disorders, the World Health Organization (WHO) revoked its Mn drinking water limit $\left(0.4 \mathrm{mg} \mathrm{L}^{-1}\right)$ because naturally occurring levels were not of health concern (WHO, 2011). We argue that the data needs to be reassessed and the drinking water limit reconsidered.

Numerous papers have explored the relationship between $\mathrm{Mn}$ and As in groundwater. Early work demonstrated that $\mathrm{Mn}$ oxide reduction can stimulate dissolved As(III) oxidation and immobilization, and later experimentation by Ehlert et al. (2016) highlighted that greater Mn-oxide content in contaminated paddy soils lead to increased As retention. Field scale observations noting an inverse relation between dissolved $\mathrm{Mn}$ and As in groundwater have been attributed to this phenomenon, as well as variable redox potential $\left(E_{h}\right)$. Yet, few studies to date have assessed the role of DOM in the coupled biogeochemical cycling of $\mathrm{Mn}$ and As (Vega et al., 2017).

Dissolved organic matter plays a key role in metal(loid) geochemistry through electron shuttling catalyzing reduction pathways, complexation processes keeping solutes in solution, and labile organic carbon fueling heterotrophic microbial metabolisms. Recent advances in fluorescent and absorbance spectroscopic techniques have permitted qualitative analyses of DOM as it relates to As mobilization, and fluorescence excitation emission matrices (EEMs) coupled with a PARAFAC model revealed associations between DOM and As, but did not include Mn (Kulkarni et al., 2016). The purpose of this study was therefore to investigate the role of DOM in coupled Mn and As biogeochemical cycling by evaluating associations between these metal(loid)s in sites with statistically different DOM composition. This presentation emphasizes recently published work in Murshidabad, India, but also includes ongoing work in the Claromecó river basin of Argentina.

\section{METHODS}

\subsection{Study area}

Murshidabad, a district in West Bengal, India, is bisected by the north-south flowing River Bhagirathi. West of the river, aquifer sediments are reddish brown and are of Pleistocene age, whereas dark gray Holocene sediments dominate the east. Several studies have reported contrasting As concentrations in the Holocene (high As) and Pleistocene (low As) aquifers, and more recent work has revealed contrasting DOM quality in these distinct systems.

The Claromecó fluvial basin (CFB) is situated in the southern Chaco-pampean plain of Argentina. Late Pleistocene-Holocene aquifer sediments constitute the top of the sedimentary sequence covering the middle and lower basin, and are greenish-brown, mostly volcaniclastic and deposited by fluvio-eolian processes (Sosa et al., 2017).

\subsection{Sampling and analysis}

In Murshidabad, 51 groundwater and 16 subsurface aquifer sediment samples were collected from two 
sites located on the west side and four sites located on the east side of the river Bhagirathi. Water samples were analyzed for dissolved cations, anions, $\mathrm{pH}$, alkalinity, $\mathrm{E}_{\mathrm{h}}$, DOC, and TDN; DOM was further characterized using EEMs followed by PARAFAC modeling. In the CFB, 29 well water samples were analyzed for dissolved cations, anions, $\mathrm{pH}$, alkalinity, and $\mathrm{E}_{\mathrm{h}}$. Aqua regia digestions were performed on subsurface sediments in both regions to determine bulk concentrations of $\mathrm{As}, \mathrm{Fe}$, and $\mathrm{Mn}$; XRF was also employed in the CFB.

\section{RESULTS}

\subsection{Aquifer metal(loid) geochemistry}

Within Murshidabad, the WHO limits for As $(10 \mu \mathrm{g}$ $\left.\mathrm{L}^{-1}\right)$ and $\mathrm{Mn}\left(0.4 \mathrm{mg} \mathrm{L}^{-1}\right)$ were exceeded in $78 \%$ and $73 \%$ of the surveyed tubewells, respectively. Three sites were characterized by high concentrations of both As $\left(\sim 330 \mu \mathrm{g} \mathrm{L}^{-1}\right)$ and $\mathrm{Mn}\left(\sim 0.8 \mathrm{mg} \mathrm{L}^{-1}\right)$ ["HMHA"], while the remaining three sites had high $\mathrm{Mn}(\sim 1 \mathrm{mg}$ $\left.\mathrm{L}^{-1}\right)$ but low As $\left(\sim 9 \mu \mathrm{g} \mathrm{L}^{-1}\right)$ ["HMLA"]. HMLA sites had higher $\mathrm{E}_{\mathrm{h}}$ but lower As and Fe concentrations, than HMHA sites. Arsenic concentrations exceeded the WHO limit in all CFB wells $\left(\sim 83 \mathrm{ug} \mathrm{L}^{-1}\right)$, whereas Mn concentrations were consistently low $(\sim 0.003 \mathrm{mg}$ $\mathrm{L}^{-1}$ ). Bulk sediment concentrations for $\mathrm{Fe}, \mathrm{Mn}$, and As were statistically similar between HMHA and HMLA sites in Murshidabad, as well as both spatially and with depth in the CFB.

\subsection{DOM-PARAFAC model}

Four DOM components were determined by the PARAFAC model in Murshidabad: (C1) a terrestrial humic-like component; (C2) a humic-like component influenced by agriculture and wastewater; (C3) a protein-like component; and (C4) a microbial humiclike component (Fig. 1). Component 1 was significantly more abundant in HMHA sites, $\mathrm{C} 3$ and $\mathrm{C} 4$ were significantly more abundant in HMLA sites, and $\mathrm{C} 2$ was statistically similar between HMHA and HMLA sites.

\section{CONCLUSIONS}

The HMHA aquifers have reducing redox potentials that can mobilize $\mathrm{Fe}, \mathrm{Mn}$, and As, and the presence of humic-like DOM may be catalyzing these processes. Further, a greater proportion of wells in HMHA sites were saturated with respect to rhodochrosite relative to HMLA sites. This implies a net sink for Mn in HMHA sites, yet Mn concentrations were similar throughout all sites. It is postulated that rhodochrosite precipitation is inhibited by complexation mechanisms with humic-like DOM, keeping Mn in solution. In HMLA aquifers, Mn oxide reduction may be oxidizing As(III) and enhancing the potential re-adsorption of $\mathrm{As}(\mathrm{V})$ onto un-reduced or freshly precipitated Fe oxides. The fact that $\mathrm{Mn}$ concentrations are high in the presence of both humic-like and protein-like DOM suggests that
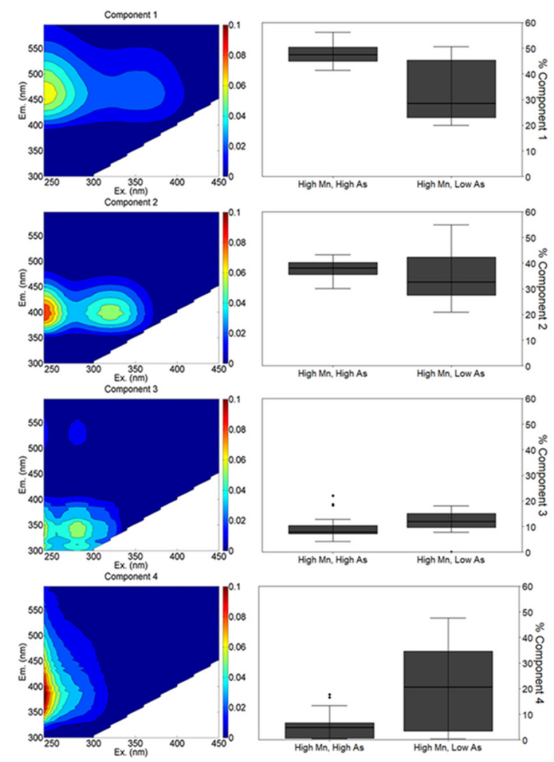

Figure 1. Excitation emission matrices (EEMs) for the four components of the DOM PARAFAC model and their relative distributions in high Mn, high As (HMHA) and high Mn, low As (HMLA) sites.

Mn mobilization may be independent of DOM quality. Future work necessitates experimental validation of the processes in Murshidabad and the application of fluorescence spectroscopic techniques in the CFB to understand the role of DOM quality in a high As, low Mn scenario.

\section{ACKNOWLEDGEMENTS}

The authors are grateful to NSF, K-State, CONACYT, and Sigma Xi for making this work possible.

\section{REFERENCES}

Ehlert, K., Mikutta, C. \& Kretzchmar, R. 2016. Effects of manganese oxide on arsenic reduction and leaching from contaminated floodplain soil. Environ. Sci. Technol. 50: 9251-9261.

Kulkarni, H. V., Mladenov, N., Johannesson, K. H. \& Datta, S. 2016. Contrasting dissolved organic matter quality in groundwater in Holocene and Pleistocene aquifers and implications for influencing arsenic mobility. Appl. Geochem. 77: 194-205.

Sosa, N.N., Zárate, M.A. \& Beilinson, E. 2017. Dinámica sedimentaria neógena y cuaternaria continental de la cuenca del arroyo Claromecó, Argentina. Latin. Am. J. Sediment. Basin. Anal. 24(2): 1-19.

Vega, M.A., Kulkarni, H.V., Mladenov, N., Johannesson, K., Hettiarachchi, G.M., Bhattacharya, P., Kumar, N., Weeks, J., Galkaduwa, M. \& Datta, S. 2017. Biogeochemical controls on the release and accumulation of $\mathrm{Mn}$ and As in shallow aquifers, West Bengal, India. Fron. Environ. Sci. doi: 10.3389/fenvs.2017.00029.

WHO 2011. Guidelines for Drinking-Water Quality. 4th ed. World Health Organization, Geneva, 541p. 